\title{
REGIMES INTERNACIONAIS SOBRE SERVIÇOS E INVESTIMENTOS: O PADRÃO AMERICANO TRADUZIDO NO USMCA ${ }^{1}$
}

\author{
Neusa Maria Pereira Bojikian²
}

\begin{abstract}
Procura-se neste artigo examinar o desenvolvimento dos regimes internacionais sobre o comércio de serviços - especificamente serviços financeiros, telecomunicações e serviços digitais - e sobre investimentos, colocando em perspectiva comparada o Tratado Norte-Americano de Livre Comércio (North American Free Trade Agreement - NAFTA) e o Acordo Estados Unidos-México-Canadá (United States-Mexico-Canada Agreement - USMCA). A administração Donald Trump toma o deficit comercial como critério para precisar até que ponto outros países têm "se aproveitado" dos Estados Unidos. Sendo assim, busca obsessivamente aumentar as exportações e diminuir as importações do país. As regras sobre o comércio de serviços e sobre investimentos são estratégicas para contribuir com o sinal positivo nessa equação. Logo, elas ocupam lugar de destaque na agenda comercial atual. Não obstante, tais regras refletem muitos objetivos bipartidários de longa data. Na década de 1990, foram inseridas forçosamente pelos negociadores americanos nos fóruns comerciais internacionais a fim de servir de instrumento para o país enfrentar a concorrência econômica. Nos dias atuais, com o USMCA, que espelha muito do conteúdo do Acordo de Parceria Transpacífica (Trans-Pacific Partnership - TPP), tornam a servir de instrumento em favor das estruturas políticas e econômicas dos Estados Unidos.
\end{abstract}

Palavras-chave: regimes internacionais; acordos comerciais; comércio de serviços; investimentos externos.

\section{INTERNATIONAL TRADE REGIMES IN SERVICES AND INVESTMENTS: THE AMERICAN STANDARD INFERRED FROM THE USMCA}

The article seeks to examine the development of international trade regimes in services - specifically financial services, telecommunications and digital services - and in investment, drawing a comparison between the North American Free Trade Agreement (NAFTA) and the United States-Mexico-Canada Agreement (USMCA). The Trump Administration takes the trade deficit as a yardstick to determine just how far other countries have "taken advantage" of the United States. It has been seeking obsessively to increase exports and reduce imports from the country. Since US services sector represents an asset to the economy and a driving force for job creation in the country, the rules on trade in services and investment have been taken as strategic and occupied a prominent place in the current trade agenda. Nevertheless, such rules reflect many long-standing bipartisan goals. In the 1990s they were forcibly inserted by American negotiators in the international trade forums in order to favoring in the greatest extent the US in the economic competition. Nowadays, with the USMCA, which mirrors much of the content of the Trans-Pacific Partnership (TPP), they again work in favor of the political and economic structures of the United States.

Keywords: international regimes; trade agreements; trade in services; foreign investments.

1. Este artigo é um resultado parcial de minha pesquisa em nível de pós-doutorado junto à Universidade Estadual de Campinas (Unicamp) e ao Instituto Nacional de Ciência e Tecnologia para Estudos sobre os Estados Unidos (INCT-INEU), no período de julho de 2017 a junho de 2018. Agradeço aos professores doutores Sebastião C. Velasco e Cruz e Tullo Vigevani pelas leituras e pelos comentários sobre o tema desta pesquisa.

2. Pesquisadora do INCT-INEU e do Instituto de Estudos Econômicos e Internacionais da Universidade Estadual Paulista (IEEI-Unesp). E-mail: <neusa.bojikian@gmail.com>. 


\section{REGÍMENES INTERNACIONALES SOBRE SERVICIOS E INVERSIONES: EL ESTÁNDAR ESTADOUNIDENSE INFERIDO DEL USMCA}

El objetivo de este capítulo es examinar los regímenes internacionales sobre el comercio de servicios, específicamente servicios financieros, telecomunicaciones y servicios digitales, y sobre inversión, poniendo em perspectiva comparativa el Tratado de Libre Comercio de América del Norte (TLCAN) y el Tratado entre México, Estados Unidos y Canadá (T-MEC). La administración de Donald Trump toma el déficit comercial como un criterio para especificar en qué medida otros países se han "aprovechado" de los Estados Unidos. Por lo tanto, busca obsesivamente aumentar las exportaciones y disminuir las importaciones del país. El comercio de servicios y las reglas de inversión son estratégicos para contribuir ao signo positivo en esta ecuación. Por lo tanto, ocupan un lugar destacado en la agenda comercial actual. Sin embargo, tales reglas reflejan muchos objetivos bipartidistas de larga data. En la década de 1990, los negociadores estadounidenses los insertaron a la fuerza en foros de comercio internacional para que el país hiciera frente a la competencia económica. Actualmente con el T-MEC, que refleja gran parte del contenido de la Asociación Transpacífica (TPP), una vez más tales temas están sirviendo como un instrumento para favorecer las estructuras políticas y económicas de los Estados Unidos.

Palabras clave: regímenes internacionales; acuerdos comerciales; comercio de servicios; inversiones extranjeras.

JEL: D79; D7; F1; F13; F14; F15.

\section{INTRODUÇÃO}

Desde a fase da campanha eleitoral, o discurso do entáo candidato Donald Trump indicava que haveria uma inflexão na política comercial, e a questão inescapável entre estudiosos, políticos e operadores do comércio era se sua administração traduziria tal discurso em açóes políticas.

Já investido de poder e logo na estreia de sua administração, o presidente Trump assinou as ordens executivas para a retirada dos Estados Unidos do Acordo de Parceria Transpacífica (Trans-Pacific Partnership - TPP) e para o início da renegociação do Tratado Norte-Americano de Livre Comércio (North American Free Trade Agreement - NAFTA), ${ }^{3}$ constituído no início da década de 1990. O primeiro náo atenderia aos interesses dos Estados Unidos ${ }^{4}$ e o último necessitaria passar por uma revisão completa.

Cumpridas as etapas exigidas por lei, as negociaçóes para a chamada revisão do NAFTA foram iniciadas e, em 30 de novembro de 2018, chegou-se a um acordo, que passou a ser conhecido pelo acrônimo USMCA (United States-Mexico-Canada Agreement, o Acordo Estados Unidos-México-Canadá) e referido por Trump como "groundbreaking achievement", ou seja, uma "conquista inovadora” (Rauhala, 2018).

3. Disponivel em: <https://www.nafta-sec-alena.org/Home/Texts-of-the-Agreement/North-American-Free-Trade-Agreement> . 4. Alguns analistas apontam que, embora tenha incorporado regras sobre empresas estatais, o TPP não contempla disposições aplicáveis sobre a manipulação de moeda (Schneider-Petsinger, 2017). 
O NAFTA, constituído na década de 1990, foi um marco na história das negociaçóes comerciais internacionais, tornando-se a referência no que diz respeito a regras sobre o comércio internacional de serviços e de investimentos em todas as negociaçóes das quais os Estados Unidos participaram.

O padrão americano, institucionalizado com o NAFTA, passou a rivalizar com aquele institucionalizado pelo Acordo Geral sobre o Comércio de Serviços (General Agreement on Trade in Services - GATS), que resultou da Rodada Uruguai de Negociações Comerciais Multilaterais e ficou conhecido como GATS 1994. Uma das principais preocupaçóes dos países refratários à ideia de incluir serviços na agenda dos fóruns comerciais internacionais correspondia ao fato de esses serviços envolverem objetos de políticas públicas (Tussie, 1993).

A depender das regras estabelecidas, os governos poderiam se achar privados da possibilidade de manejar, conforme seus próprios objetivos e necessidades, suas instituiçóes. O modelo estabelecido com o NAFTA costumava ser associado a um instrumento de concessão de amplo espaço regulatório pertencente, por princípio, ao Estado e de interesse de seus cidadãos.

Mobilizados por intenso lobby dos agentes econômicos envolvidos com essas áreas, os negociadores americanos se concentraram nesses temas. Ao México restou oferecer a oportunidade de que os Estados Unidos necessitavam para internacionalizar suas próprias regras sobre o comércio de serviços e de investimentos.

No contexto atual, tais temas tornam a se destacar na agenda do Escritório do Representante de Comércio dos Estados Unidos (United States Trade Representative - USTR), órgão responsável por negociar os acordos comerciais do país. ${ }^{5}$ Sendo assim, parece pertinente discutir a seguinte questão: como se configuram os novos termos e condiçóes relativos ao comércio sobre serviços e de investimentos?

O objetivo deste artigo é examinar o desenvolvimento dos regimes internacionais no que diz respeito ao comércio de serviços - especificamente serviços financeiros, telecomunicaçóes e serviços digitais - e em relação a investimentos, comparando o NAFTA e o USMCA.

$\mathrm{O}$ argumento defendido aqui é que os negociadores americanos que compóem a administração Trump, apesar da retórica crítica aos acordos assinados anteriormente, tendem a se basear nas regras acordadas no TPP, o que quer dizer que não rompem com a política setorial defendida anteriormente. Há de se ressaltar, entretanto, que o USMCA introduz uma mudança que tende a chamar mais atenção, e esta refere-se a regras sobre investimentos, sobretudo o sistema

5. Disponível em: <https://bit.ly/2vC2go8>. 
Investor-State Dispute Settlement (ISDS), atinente à resolução de conflitos, baseado na arbitragem internacional, o qual coloca em disputa direta investidor e Estado. Além disso, argumenta-se que regras sobre serviços e investimentos contidas no USMCA tendem a constituir o novo padrão americano a ser defendido junto a outros fóruns de negociação. $\mathrm{O}$ acordo, de modo geral, reflete uma nova lógica econômica, favorável aos Estados Unidos.

O texto divide-se em três seções, além desta parte introdutória e da conclusão. Na primeira, contextualiza-se o papel do México nas negociações do NAFTA e do USMCA. Na segunda, examinam-se as regras estabelecidas no NAFTA e no USMCA, buscando corroborar o argumento de que o USMCA se assemelha ao TPP. Por fim, na terceira seção, analisam-se as regras relativas a investimentos, buscando identificar os principais elementos.

\section{NAS NEGOCIAÇÕES DO NAFTA E DO USMCA: O PAPEL DO MÉXICO}

Contextualizar as iniciativas do México nessas negociaçóes é o propósito desta seção. O pressuposto que se tem em conta é que tal país ofereceu uma oportunidade singular aos Estados Unidos para que atingissem objetivos de política comercial, primeiramente por meio do NAFTA e depois por meio do USMCA.

\subsection{Início de 1990}

O descontentamento dos negociadores americanos com os rumos que as negociaçóes da Rodada Uruguai de Negociaçóes Comerciais Multilaterais, especialmente sobre o acordo de serviços (GATS-Rodada Uruguai), estavam tomando é um componente fundamental da equação que vai resultar no processo de institucionalização do comércio de serviços no âmbito dos acordos preferenciais de comércio (APCs) de forma incomparavelmente abrangente. Isso configura, entretanto, apenas um lado da equação. Há de se considerar o valor adicional atribuído pelo então governo mexicano a um acordo a ser constituído com os Estados Unidos, o que o fez aceitar diversas demandas apresentadas pelos negociadores americanos.

A disposição de Carlos Salinas de Gortari, à época presidente do México, de negociar a qualquer custo um acordo comercial com a superpotência vizinha, na dobra da década de 1980 para a de 1990, surgiu em tempo adequado para acomodar a melhor alternativa que dividiria as atenções dos negociadores americanos até então concentrados no GATS-Rodada Uruguai.

No final de fevereiro de 1990, o presidente Salinas telefonou para o presidente George Bush para manifestar sua disposiçâo: "Eu gostaria de fazer um acordo de livre-comércio com os Estados Unidos” (CoolBen, 2014, tradução nossa). Do outro lado, a primeira iniciativa foi negociar um entendimento de que o 
objetivo seria conformar um acordo abrangente, envolvendo essencialmente quatro temas: bens manufaturados, serviços, investimentos e propriedade intelectual. Os negociadores americanos deixaram claro "que não seria um regime de tratamento especial”. Os negociadores mexicanos interpretaram que lhes restaria aceitar a condicionalidade ou não haveria acordo, o que os levou a responder: "Claro" (CoolBen, 2014, tradução nossa).

A associação do Canadá à negociação bilateral que se iniciava entre seus vizinhos foi uma questáo de tempo. No começo de setembro de 1990, Brian Mulroney, primeiro-ministro do Canadá, manifestou diretamente ao presidente Bush sua intenção de fazer parte das negociaçôes. Aparentemente, o primeiro-ministro ficou preocupado com a possibilidade de os Estados Unidos poderem tirar vantagem de dois acordos bilaterais na América do Norte, constituindo um arranjo do tipo hub-and-spoke, ou eixo e raio. Em tal arranjo, o país-eixo possui acesso preferencial aos mercados dos países-raio, enquanto os países-raio possuem acesso apenas ao país-eixo. O raciocínio era que isso desviaria não só o comércio como também o fluxo de investimentos externos para os Estados Unidos. Ademais, receava-se que o arranjo se expandisse rapidamente por toda a América Latina. Finalmente, as autoridades canadenses calculavam que o poder de compra dos mexicanos poderia aumentar com o acordo, conforme ocorrera nos mercados de Portugal e da Espanha ao se tornarem Estados-membro da União Europeia - podendo o Canadá, portanto, perder oportunidades. ${ }^{6}$

A posição dos negociadores americanos era mais confortável diante dos demais. O grau de dependência comercial do México em relação aos Estados Unidos era flagrante. Em 1990 e 1991, acima de 65\% das exportaçôes mexicanas tiveram como destino os Estados Unidos. Em contrapartida, apenas 6\% das exportaçóes dos Estados Unidos tiveram como destino o México. A dependência do Canadá também não era diferente, pois cerca de $65 \%$ de suas exportaçóes seguiram para os Estados Unidos em 1992, enquanto este país destinou aproximadamente $20 \%$ de suas exportaçóes para o Canadá neste mesmo ano (Enciso e Castro, 1992).

Apesar da relação assimétrica de poder, a articulação interna necessária para que a administração obtivesse autorização para negociar efetivamente o NAFTA exigiu grande esforço. Richard A. Gephardt, então líder da maioria na Câmara, esclareceu as condiçóes: "Estamos dando essa autoridade condicionalmente.

6. Houve um acordo prévio entre negociadores americanos e canadenses, em que ficou estabelecido que, se os canadenses concluíssem que não poderiam aceitar determinados termos e condições, simplesmente ficariam de fora; e, caso os americanos não conseguissem constituir um acordo com os mexicanos, não haveria prejuízo ao acordo bilateral já existente entre Estados Unidos e Canadá (Canada-United States Free Trade Agreement - CUSFTA), de 1988. Este foi efetivamente o primeiro acordo bilateral de comércio a conter provisões legais sobre o comércio de serviços. Disponivel em: <https://bit.ly/2KqPHSU>. 
Nós vamos estar olhando sobre os ombros de nossos negociadores" (Mazza, 2001, p. 76, tradução nossa).

Um dos compromissos assumidos pela administraçáo junto ao Congresso era a preservação, a qualquer custo, do status quo das leis comerciais domésticas. Em julho de 1991, em sessóes plenárias em Washington presididas pelos respectivos negociadores-chefes do NAFTA, Julius Katz disse que o país não mudaria qualquer lei comercial doméstica para ajustar-se às demandas do Canadá ou do México. Outra promessa era passar para o Congresso a minuta detalhada do acordo e em tempo hábil, a fim de que eventuais alterações pudessem ser incorporadas - o que não havia sido exigido na época das negociações do CUSFTA.

\subsection{7}

Diferentemente do período anterior, as negociações que levaram à constituição do USMCA não partiram de uma decisiva iniciativa do México. Como destacado na introdução, rever os termos e condiçóes estabelecidos no NAFTA era uma meta defendida fundamentalmente pela administração Trump. Isso não significou, entretanto, uma situação mais favorável ao México. $\mathrm{O}$ pressuposto que se tem em consideração aqui é que a alternativa de não aceitar a renegociação, pondo um fim ao NAFTA, não foi de fato ponderada pelo México.

Trump criticou duramente o NAFTA desde o início de sua campanha. O acordo teria sido responsável pela perda de emprego e pelo achatamento dos salários em estados tradicionalmente dedicados à manufatura pesada, como Michigan, Pensilvânia e Wisconsin. Para o presidente, este seria "o pior acordo comercial da história do país” (Partington, 2018, tradução nossa).

A orientação política impressa no America First (América Primeiro), que enfatiza o nacionalismo cultural, o protecionismo econômico e o intervencionismo seletivo, em contraposição ao cosmopolitismo, ao liberalismo e às políticas internacionalistas, seduz os chamados "americanos esquecidos", classe de americanos brancos, medianamente educados, economicamente vulneráveis e socialmente deslocados que, assim como o então candidato Donald Trump, identifica os mexicanos e os acordos comerciais como inimigos dos Estados Unidos (Matthews, 2018).

A questão é que desde a constituiçâo do NAFTA foi-se criando um vínculo forte entre as três economias, caracterizando uma interdependência assimétrica, especialmente entre Estados Unidos e México. Resultado dificilmente contestável indica que o acordo reforçou a alta sensibilidade dos setores econômicos mexicanos à evolução econômica nos Estados Unidos (Lederman, Maloney e Servén, 2005; Villarreal, 2010). 
Após a implementação do acordo, quase $70 \%$ das exportações do México para os Estados Unidos e 50\% das exportaçôes destes para o México receberam tratamento isento de impostos. Os demais direitos foram eliminados ao longo de quinze anos após o início da vigência do acordo. A liberalização do setor de serviços significou a entrada de inúmeras empresas americanas nos mais diversos setores do mercado mexicano. As regras sobre investimentos, com ampla proteção aos investidores estrangeiros, bem como as regras sobre direitos de propriedade intelectual, presentes no NAFTA, predominantemente favoráveis às empresas americanas, também acabaram aprofundando a relação comercial entre as duas economias.

Desde 1999, o México mantém uma balança comercial superavitária com os Estados Unidos (tabela 1), ficando bem atrás da China, mas disputando proeminência com parceiros comerciais históricos do país norte-americano, como a Alemanha e o Japão. ${ }^{7}$

O México é o principal destino dos investimentos originários dos Estados Unidos, assegurando uma margem acima de 35\%, desde 2009, e superando os $40 \%$, desde 2015, do estoque de investimentos destinados à América do Sul e à América Central (não inclusos os paraísos fiscais). ${ }^{8}$

Diante das circunstâncias, coube ao México reagir, na medida do possível, para reduzir os custos que lhe poderiam ser atribuídos por essa nova orientação política americana - mudar a trajetória poderia ser extremamente custoso. Tendo em conta o conceito de path dependency, a passagem do tempo tende a aprofundar os compromissos com a trajetória escolhida anteriormente, com o emprego de recursos materiais e cognitivos, levando a um forte enraizamento. Pierson (2000, p. 251), ao trazer o conceito para o campo da política, o associa a "dinâmicas de autorreforço ou feedback positivo em um sistema político".

Enquanto o governo mexicano dizia que não negociaria sob pressão, as autoridades americanas anunciavam que seria lançada uma nova investigação sobre as tarifas de automóveis (carros e caminhóes), a fim de verificar se as importaçôes estariam prejudicando a indústria automobilística do país.

7. Dados sobre o comércio internacional de bens e serviços por país estão disponíveis em: <https://bit.ly/2P9Evyq >. 8. América do Sul: Argentina, Brasil, Chile, Colômbia, Equador, Peru, Venezuela, outros; América Central: Costa Rica, Honduras, Panamá, outros. Neste conjunto, não estão inclusos Barbados, Bermudas, República Dominicana, Ilhas Britânicas e llhas Caribenhas. Muitas dessas ilhas atraem altos índices de investimentos em função dos benefícios fiscais. 


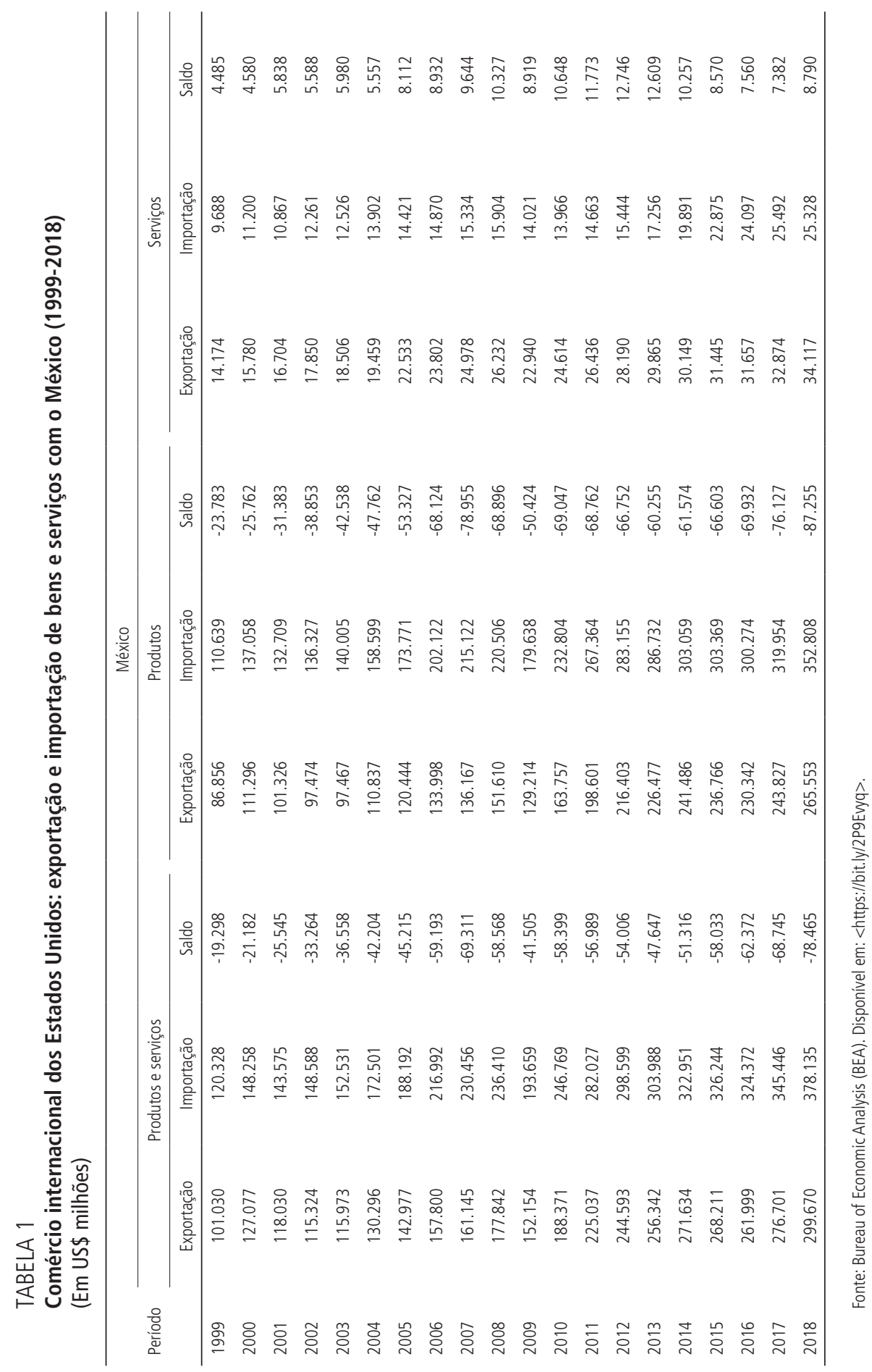




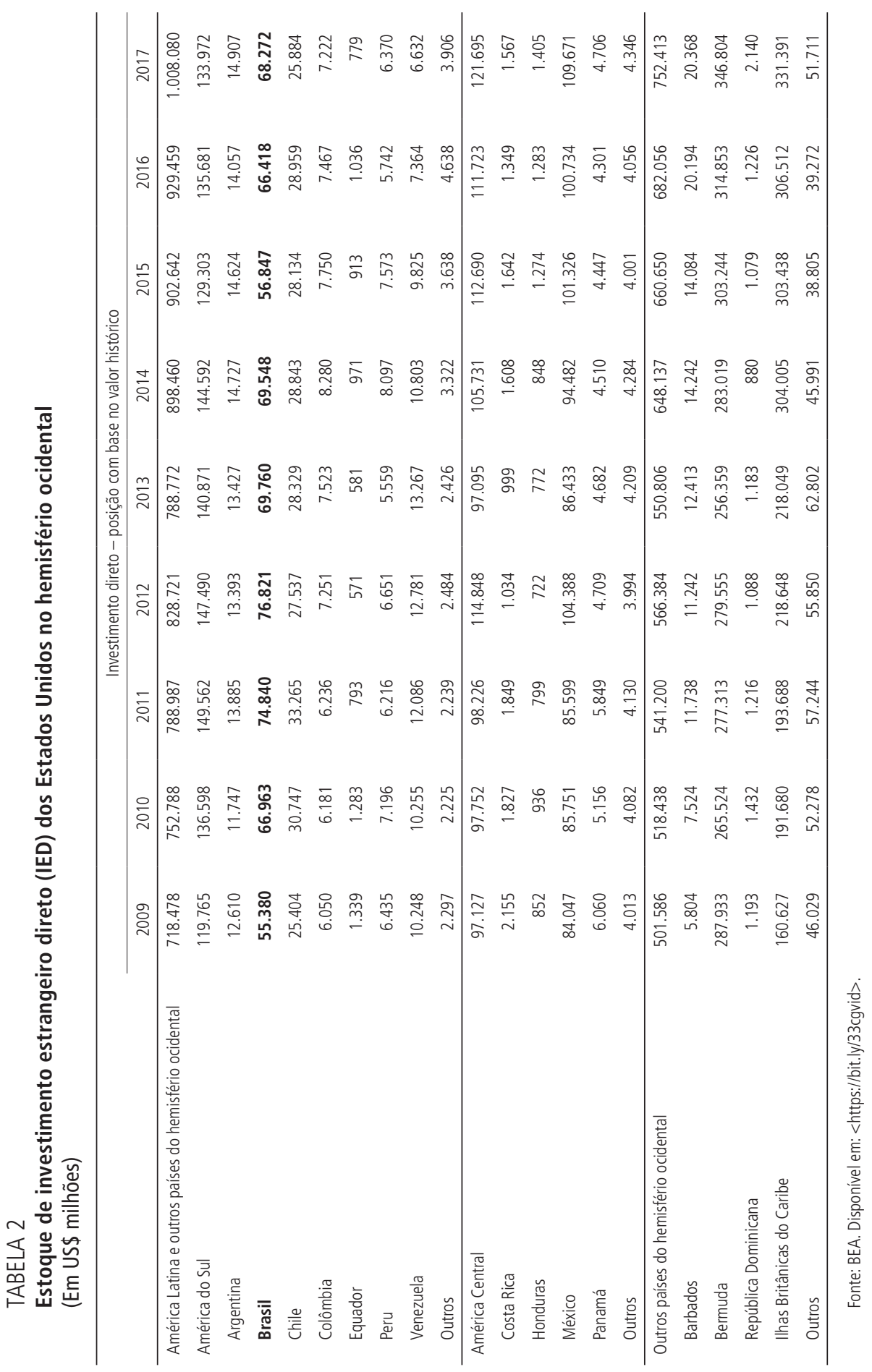


Além disso, a tática colocada em prática pelos negociadores americanos, encabeçados por Robert Lighthizer (representante do USTR), deu-lhes a vantagem que esperavam. Adotaram primeiramente a clássica divide et impera, impondo uma dinâmica bilateral de negociação com o México. Nos últimos dias de negociaçóes, Chrystia Freeland (Blatchford, 2017), no papel de ministra do Comércio do Canadá, depois de enfrentar diversos insultos, teve que fazer concessôes unilaterais para que não ficasse de fora do acordo.

Hufbauer e Globerman (2018, p. 2, tradução nossa) identificam uns elementos que definem a estrutura do que chamam de "tática trumpiana". Segundo os autores, essa tática consiste nos seguintes passos: "primeiro, brade suas queixas; segundo, insulte sua contraparte; terceiro, comprometa-se com um acordo; e quarto, reivindique um magnífico sucesso”.

Voltando a observar a atuação do México, em maio de 2018, os negociadores mexicanos apresentaram uma nova oferta aos seus interlocutores americanos, contendo diferentes termos e condições (Stargardter e Lawder, 2018). Isso pode ser interpretado como uma reação às queixas bradadas pela delegação americana. Os mexicanos mais uma vez pareciam estar diante de uma situação com saída única - o acordo, qualquer que fosse -, contrariando o objetivo de acordo equilibrado, previamente sugerido pelo porta-voz de Enrique Peña Nieto, então presidente do México.

O governo mexicano, destacando o "impacto benéfico que o NAFTA teve na competitividade da indústria manufatureira e agroindústria mexicana” (Peña, 2017, tradução nossa), ou seja, o papel do NAFTA na inserção internacional do México, já havia submetido ao Senado o que considerava prioridade nas renegociaçóes. Uma dessas prioridades seria aproveitar as supostas oportunidades oferecidas pela economia do século XXI, o que envolveria: i) refletir o potencial econômico e as oportunidades derivadas da reforma energética mexicana de 2013-2014; ii) estimular o desenvolvimento da economia digital, o comércio eletrônico e a prestação de serviços financeiros por meio de plataformas digitais; iii) facilitar o acesso aos mercados dos Estados Unidos e do Canadá para instituiçóes financeiras mexicanas; e iv) promover uma integração maior dos mercados de telecomunicações dos três países.

Por fim, dado que o NAFTA seria um fator de estabilidade e certeza na integração econômica da América do Norte, caberia às partes cooperar para promover o investimento na regiáo, de modo a modernizar os mecanismos de resolução de disputas no acordo, incorporar disposiçóes relativas à troca de informaçôes entre as autoridades dos três países e proporcionar segurança jurídica aos fornecedores nos procedimentos de contrataçáo pública. 


\section{COMÉRCIO DE SERVIÇOS: REGRAS ESTABELECIDAS NO NAFTA E NO USMCA}

\subsection{A arquitetura da liberalização: separação por capítulos e Lista Negativa}

Um dos elementos definidores do modelo NAFTA, e agora do USMCA, é a separaçáo entre o que se convencionou chamar de comércio transfronteiriço e comércio por meio da presença local ou do IED. No GATS, o primeiro é conhecido como Modo 1 e o último como Modo 3. ${ }^{9}$

Os princípios da não discriminação e da liberalização, aceitos em favor da reconstrução do sistema de comércio afetado pela crise do entreguerras, pareciam inaplicáveis às transaçóes internacionais de serviços. As divergências que marcaram as negociaçóes para a inserção de serviços no sistema multilateral de comércio envolviam uma série de dilemas.

$\mathrm{O}$ que significaria não discriminação nesse contexto? (...) Dar tratamento nacional aos fornecedores de serviços, assegurando-lhes a "presença comercial" como queriam os Estados Unidos e demais países da OCDE [Organização para a Cooperação e o Desenvolvimento Econômico]? Mas, se é assim, como separar serviço de investimento direto? E como negar este à pessoa física do empregado no setor de serviços? O "direito de estabelecimento" pleiteado para as empresas náo teria como contrapartida a garantia do "direito de residência" ao trabalhador individual? (Cruz, 2017, p. 169-170).

A definição por modos foi a solução encontrada pelos signatários para contornar esses dilemas. Resultou que no GATS há uma interação maior entre serviços e investimentos.

No NAFTA e no USMCA, entretanto, conforme a preferência dos Estados Unidos, esses temas foram tratados separadamente. Tal separação não é meramente técnica ou de forma, mas sim de substância. O capítulo sobre investimento tende a controlar todas as provisóes de investimento de bens e serviços (exceto serviços financeiros). O capítulo referente ao comércio transfronteiriço de serviços, por sua vez, é exclusivamente dedicado à liberalização dos serviços prestados sem presença comercial. Pode-se dizer que o padrão adotado no NAFTA e no USMCA tende a induzir uma liberalização maior em serviços, na medida em que a separação inviabiliza uma abordagem quid pro quo ${ }^{10}$ mensurada com base no conjunto de quatro modos de comércio de serviços.

Quando se examinam as listas de ofertas de cada país no GATS, o que se nota é que as ofertas no Modo 3 superam sensivelmente as no Modo $1 .{ }^{11} \mathrm{~A}$ razão pode

9. Há, ainda, o Modo 2 (consumo no exterior) e o Modo 4 (movimento temporário de pessoas naturais) (WTO, 1994). 10. A noção de quid pro quo é a essência de um resultado equivalente ao "ganha-ganha" ou da "negociação de acordos sem concessões" (Fischer, Ury e Patton, 2005).

11. Disponivel em: $<$ https://bit.ly/2NX5gCe>. 
ser associada ao fato de que as ofertas no Modo 3 tendem a atrair investimentos e, portanto, a possibilidade de aumento no índice de empregos, na transferência de tecnologia e nas exportaçóes. Por outra parte, ofertas correspondentes ao Modo 1 não apenas tendem a não contribuir para o aumento desses índices como, em alguns casos, podem comprometer os fundamentos macroeconômicos. Concessôes no Modo 1 afetam a conta de capital (Beck, 2000).

Enquanto no GATS os signatários puderam manejar suas ofertas, levando em conta tais fundamentos, a divisão de capítulos, inaugurada no NAFTA e mantida no USMCA, inviabilizou essa prática. Pode-se pensar que seria inaceitável apresentar ofertas relativas ao Modo 3, a constar do capítulo Investimento (capítulo 11 do NAFTA e 14 do USMCA), e não apresentar qualquer oferta correspondente ao Modo 1, a constar do capítulo Comércio transfronteiriço (capítulo 12 do NAFTA e 15 do USMCA) - ou seja, conceber um capítulo vazio sobre comércio transfronteiriço.

Outro elemento de destaque do NAFTA refere-se ao procedimento de listar os compromissos de liberalização. Enquanto no GATS-Rodada Uruguai os negociadores convergiram para a adoção do procedimento Lista Positiva, ou bottom-up, apoiado sobretudo pelos negociadores europeus e pelos negociadores de países em desenvolvimento, no NAFTA adotou-se a Lista Negativa, ou top-down.

A discussão no GATS-Rodada Uruguai girou em torno da preservação do espaço regulatório, o que tende a ser afetado com a adoção da Lista Negativa. No NAFTA, nota-se que os negociadores americanos fizeram valer suas preferências. Uma das justificativas apresentadas dizia que a Lista Negativa seria um corretivo contra a abordagem setorial, ou seja, a negociação conduzida setor por setor, que está relacionada à Lista Positiva e que supostamente prejudica a abrangência e a agilidade da liberalizaçáo (Drake e Nicolaïdis, 1992).

Em razão da diferença no grau de desenvolvimento entre as economias envolvidas, o México seria o menos favorecido com a adoção de tal modelo. No entanto, a importância atribuída pelos negociadores mexicanos ao acordo com os Estados Unidos pesou mais que a necessidade de manter o espaço regulatório. Nas análises de Mace e Bélanger (2007, p. 27), há indicaçôes de que o México sinalizou um desejo de adaptar tal procedimento a outro mais favorável ou a algum que permitisse tratamento diferenciado. Entretanto, como abordado na seção 2 deste artigo, os negociadores americanos demarcaram, desde o início, uma zona rígida de possível acordo, sinalizando aos seus interlocutores mexicanos que não alterariam suas posiçóes.

A partir do NAFTA, a Lista Negativa passou a ser um padrão aceito pelos parceiros dos Estados Unidos. No âmbito das negociaçóes do TPP, as partes pareciam convencidas da suposta vantagem oferecida por tal procedimento. 
Em meados dos anos 2000, justamente para uma plateia de países asiáticos, representantes do governo americano já apresentavam as críticas à Lista Positiva, acrescentando, junto às desvantagens alegadas na época das negociaçóes do GATS-Rodada Uruguai e do NAFTA - processo de troca de informação mais demorado e liberalização em passos lentos -, mais duas: "novos setores requerem novas negociaçôes" e "mais tempo é gasto para definir setores cobertos [a figurar na Lista Positiva] do que para encontrar meios para reformar setores sensíveis". ${ }^{12}$

No USMCA, o procedimento não seria diferente. Espelhando o TPP e o United States-Korea Free Trade Agreement (KORUS FTA), o novo acordo se configurou baseado em dois anexos a abrigar as respectivas exceçóes ou, conforme a linguagem dos APCs, as medidas não conformes, que significam medidas de proteção para assegurar aos respectivos governos liberdade para se implementarem futuras políticas comerciais.

$\mathrm{O}$ anexo I abriga as medidas de proteção existentes (as atuais), as quais não podem ser majoradas, pois estão sujeitas à regra standstill (regra do congelamento). Além disso, em função da regra ratched (regra da catraca), futuras liberalizaçóes, sejam por iniciativa unilateral ou por força de arranjos comerciais com terceiros países, são imediatamente consolidadas, ou seja, tornam-se parte da obrigação vinculada ao acordo. ${ }^{13}$ Note-se que, enquanto a regra do congelamento fixa o status quo regulatório, a da catraca requer que alteraçóes futuras não afetem negativamente o grau de conformidade com os compromissos assumidos no âmbito do acordo.

$\mathrm{O}$ anexo II abriga as medidas e políticas de proteção sobre as quais os signatários mantêm liberdade para decidir o que fazer no futuro. Tal anexo pode ser associado a uma espécie de "depósito do espaço regulatório".

\subsection{Serviços financeiros, de telecomunicações e digitais}

\subsubsection{Serviços financeiros}

Estes serviços figuram no topo das listas de demandas dos negociadores americanos em todos os fóruns de negociação. No NAFTA, os resultados foram um marco da liberalização comercial e passaram a ser a referência para esses negociadores, que chegam buscando obter plenas concessóes relativas aos princípios: tratamento nacional e acesso a mercados.

Os mexicanos, supostamente, estavam dispostos a proceder à liberalização do setor bancário até mesmo em bases unilaterais (Cameron e Tomlin, 2000, p. 98).

12. Disponível em: <https://bit.ly/2Ksi7fe>.

13. Disponível em: <https://bit.ly/1Q6QDtR>. 
De fato, nas rodadas de negociação havidas em Dallas (fevereiro de 1992), os negociadores mexicanos fizeram amplas concessóes, como reconhecer o princípio do tratamento nacional, deixar de exigir condicionalidades sobre investimentos estrangeiros para o setor bancário e abandonar o fator de participação acionária.

Em relação ao mercado canadense, os americanos queriam chegar a um acordo que fosse mais ambicioso que o CUSFTA. Queriam, por exemplo, garantir que os bancos americanos pudessem se estabelecer no Canadá sem condicionalidades. Os canadenses, por sua vez, cobravam dos americanos promessas feitas durante as negociaçôes do CUSFTA, mas até então não cumpridas. Uma delas, feita por James Baker, secretário do Tesouro, durante a administração Ronald Reagan, previa a reforma financeira do próprio país, pondo fim à segmentação entre bancos de varejo e bancos de investimento (Glass-Steagall Act) e à proibição de operações bancárias interestaduais por força do McFadden Act. ${ }^{14}$ Os negociadores americanos, no entanto, coerentemente com o que Julius Katz havia dito em julho de 1991, recusaram-se a considerar qualquer mudança nas regulamentaçóes financeiras para contentar seus interlocutores.

No jogo endurecido pelos negociadores americanos, restou aos outros, sobretudo aos mexicanos, fazer as maiores concessóes. Além das conquistas importantes nos segmentos bancário e de valores mobiliários, os negociadores americanos (e canadenses também) obtiveram bons resultados no segmento de seguros. Os mexicanos apenas asseguraram um período de transição (seis anos depois que o acordo entrasse em vigor) até que liberalizassem integralmente o mercado. Depois disso, teriam apenas permissão para implementar as chamadas medidas prudenciais. ${ }^{15}$

Assim, com o NAFTA, permitiu-se o acesso das empresas de seguro ao mercado mexicano por três diferentes maneiras: i) joint ventures com seguradoras mexicanas, de forma crescente em termos de participação acionária $(30 \% \mathrm{em}$ 1994, 51\% a partir de 1998 e 100\% a partir de 2000); ii) subsidiárias (as empresas passaram a poder se estabelecer no país primeiramente dentro da margem de $6 \%$ de participação no mercado, mas com autorização para aumentar gradualmente tal participação em até 12\% em 1999 e ilimitadamente depois de 2000); e iii) empresas que possuíam participação acionária no mercado de seguros do México poderiam atingir os $100 \%$ de participação a partir de $1996 .{ }^{16}$

14. A Lei no 69-639, do 69th Congress, de 25 de fevereiro de 1927, proíbe o estabelecimento de agências (ou seja, o crescimento orgânico, que também pode ser entendido como ramificação) interestaduais, limitando, portanto, as operações dos bancos dentro dos respectivos estados de origem. Depois, tal lei foi superada pela Riegle-Neal Interstate Banking and Branching Efficiency Act of 1994, muito embora esta última preveja que as respectivas leis estaduais continuem a controlar o procedimento para o estabelecimento de agências intraestados ou para o estabelecimento de agências dentro das fronteiras estaduais para bancos estaduais e nacionais. Disponivel em: <https://bit.ly/2OBHws7>. Acesso em: dez. 2015.

15. Para mais informações, conferir o capítulo 14 do NAFTA e ver comentários a esse respeito em Steinberg $(1994$, p. 11). 16. Para mais informações, conferir o capítulo 14 do NAFTA e ver comentários a esse respeito em Steinberg (1994, p. 11-12). 
Quando os negociadores americanos encontraram seus interlocutores nas negociaçóes do TPP, havia forte interesse entre o público em geral, tanto interno quanto externo aos Estados Unidos, em saber como se configuraria um acordo de livre-comércio depois da crise financeira de 2007-2008 e depois da aprovação da Lei Dodd-Frank. Apesar das várias críticas internas contra qualquer acordo envolvendo tal setor, vocalizadas especialmente pela senadora Elizabeth Warren (do Partido Democrata de Massachusetts), agentes da administração e do Congresso mantiveram-se firmes na contra-argumentação.

Com suficiente apoio interno, o capítulo 11 do TPP abrangeu obrigaçôes geralmente encontradas nos demais APCs assinados pelos negociadores americanos, como: nação mais favorecida, tratamento nacional, acesso a mercados, transparência e regras prudenciais. Em contrapartida, o anexo III, que traz a programaçáo de compromissos dos Estados Unidos e destaca suas medidas de exceção, mostra que muitos dos compromissos não abrangem o nível subnacional. As restriçóes americanas nesse âmbito, contidas em várias cláusulas, também podem ser vistas no setor de seguros, ironicamente um dos mais visados pelos agentes econômicos americanos no exterior.

Com o USMCA, o que se verifica é que todos esses compromissos foram novamente acordados. Um conjunto de cláusulas que não constaram do NAFTA, mas que já haviam sido discutidas no TPP (ainda que não acordadas) e foram estabelecidas no USMCA, refere-se a políticas cambiais. A preocupação central das autoridades americanas era obter, entre os membros do acordo, o compromisso de manter o regime cambial determinado pelo mercado e coibir a desvalorização competitiva.

Prevê-se no acordo o estabelecimento de um comitê macroeconômico, composto por representantes de cada um dos signatários, para discutir políticas cambiais e o estabelecimento de mecanismos de consultas entre as autoridades monetárias. Como está prevista a obrigação de divulgação mensal sobre intervençôes no mercado e estoque de dívidas, é razoável pensar que o comitê deverá questionar os objetivos das respectivas políticas cambiais. Por fim, acordou-se o estabelecimento de um sistema de solução de controvérsias sobre questóes financeiras.

O TPP serviu de referência para o USMCA também no que diz respeito à transferência de informaçóes financeiras, em formato eletrônico ou outro, dentro e fora de seu território, para o processamento de dados. Concretamente, significa que houve um acordo permitindo que instituiçóes financeiras dos países que fazem parte desse acordo - operantes no âmbito territorial coberto - processem dados dos consumidores externamente e náo precisem se submeter a obrigaçóes de manter localmente computadores e dispositivos de armazenamento necessários para processar ou armazenar informaçóes relevantes para seus negócios. 
Outro conjunto de cláusulas inspiradas no TPP e que estão nas letras do USMCA refere-se às empresas estatais (state-owned enterprises - SOEs). Para os negociadores americanos, essas empresas não operam sob critérios de transparência e não estão sujeitas à supervisão de um órgão regulador independente do governo. Tais argumentos já haviam aparecido nas negociaçóes anteriores com a Coreia do Sul e, portanto, já eram previstos no TPP (Schott, Bradford e Moll, 2006; Cooper e Nelson, 2014).

A liberalização transfronteiriça - o equivalente ao Modo 1 do GATS também pode ser pareada ao que fora acordado no TPP. Isso pode ser constatado principalmente nos serviços de informação bancária e de consultoria no setor bancário. No segmento de seguros, a liberalização transfronteiriça foi estabelecida para seguros de transportes marítimo e aéreo e resseguros; consultoria sobre seguros, risco, atuariais e liquidação; e serviços de corretagem.

\subsubsection{Serviços de telecomunicações ${ }^{17}$}

A falta de entendimento nas negociaçóes do GATS-Rodada Uruguai, que acabou afetando o cronograma e levando o setor de telecomunicaçôes a ser negociado em separado, refletiu nas negociaçôes do NAFTA, fazendo com que os serviços básicos de telefonia ficassem de fora do acordo. Isso significa que os compromissos não envolveram a obrigação de se permitir que um fornecedor de outro país operasse redes ou fornecesse serviços de transmissão de telecomunicações. ${ }^{18}$

Por outra parte, o acordo resultou na remoção das barreiras ao acesso a value-added services (VAS). $\mathrm{Na}$ tradução literal, são os serviços de valor agregado de telecomunicações. ${ }^{19} \mathrm{Na}$ prática, são todos os serviços além dos serviços básicos de chamadas de voz e transmissão de fax. Isso quer dizer que serviços como mensagem eletrônica, de voz, sistema de recuperação de dados, serviços de computação e financeiros que estáo vinculados aos de telecomunicaçôes foram negociados sob alguns princípios comuns: i) não discriminação e completa transparência; ii) limitada regulamentação, com liberdade para a marcação de preço (lei da oferta e da procura); iii) harmonização de padróes técnicos relacionados às operaçôes de telecomunicações; e iv) publicaçấo de informações que afetem o acesso e o uso dos serviços básicos de telecomunicaçóes.

Outra mudança trazida pelo NAFTA revelou-se com a permissão para o uso compartilhado de circuitos arrendados entre diferentes usuários reunidos

17. 0 capítulo 13 do NAFTA não abrange emissoras de televisão ou rádio nem fornecedores de cabo. Para mais informações, ver 0 art. 1301 no referido capítulo.

18. Para mais informações, conferir o capítulo 13 do NAFTA.

19. Para mais informações, conferir os capítulos 11,12 e 13 do NAFTA. 
por interesses empresariais em comum. Antes do acordo, as linhas eram arrendadas individualmente.

Assim como no setor financeiro, o princípio de transparência ganhou grande importância no de telecomunicaçóes, obrigando os signatários a assegurar que suas regras e regulamentaçóes referentes à emissão de licenças fossem aplicadas apenas depois das devidas notificaçóes públicas e da concessão de oportunidades para a argumentação contrária.

Note-se que as disposiçóes legais acordadas no NAFTA seguiram a normatização técnica americana, estabelecendo, em conformidade com as questôes de segurança, que qualquer dispositivo possa ser ligado à rede pública de telecomunicaçóes e seja compatível com dispositivos de outros usuários.

O acordo estabeleceu a criação de um subcomitê orientado a desenvolver um mercado norte-americano de telecomunicaçôes o mais padronizado possível e ordenou que os signatários aceitassem dados testados de qualquer certificador qualificado.

No TPP, os negociadores americanos chegaram ambicionando um acordo que ultrapassasse as liberalizaçóes anteriores, inclusive aquela assegurada no KORUS. À medida que os clientes se internacionalizam, as operadoras de telecomunicaçóes são obrigadas a expandir suas redes para acompanhá-los, o que as obriga a investir em novos pontos de presença (POPs), a implantar equipamentos de telecomunicaçóes e a ligar os POPs à sua rede global. Para que tais investimentos sejam empregados, entretanto, os agentes econômicos exigem: obrigações em matéria de acesso e utilização dos serviços básicos de telecomunicaçốes e interconexão das redes de telecomunicaçôes; independência (do Estado) do órgão regulador; e a chamada cultura de mercado.

No USMCA, todos esses compromissos foram assegurados. O capítulo 18 prevê uma série de regras que se aplicam a quaisquer medidas relativas ao acesso e à utilização de redes ou serviços públicos de telecomunicaçôes; a obrigaçôes de fornecedores de serviços públicos de telecomunicaçôes; e à prestação de VAS. No acordo, definiu-se que esses são serviços de telecomunicaçóes que, por meio de aplicativos de processamento de computador, agem "no formato, conteúdo, código, protocolo ou aspectos semelhantes das informaçóes transmitidas pelo cliente", fornecem ao cliente "informaçóes adicionais, diferentes ou reestruturadas" ou envolvem a "interaçáo com o cliente com informaçôes armazenadas" (United States of America, 2018, tradução nossa).

$\mathrm{O}$ princípio relativo à transparência aparece em várias cláusulas. $\mathrm{O}$ objetivo por trás de tais disposiçóes é, sobretudo, acabar com os requerimentos técnicos nacionais. Segundo Signoret e Bloodgood (2016, p. 389), que haviam se 
manifestado nas negociaçôes do TPP, as disposições impondo critérios e processos transparentes de licenciamento, combinadas com o procedimento Lista Negativa, podem permitir que as operadoras americanas ofereçam serviços de maior valor agregado em outros países.

Pode-se acrescentar que as operadoras americanas, principalmente, também serão beneficiadas com a política de neutralidade tecnológica, que geralmente proíbe os requisitos que ditam as escolhas tecnológicas, endossada pelos signatários.

Uma novidade trazida pelo TPP refere-se aos custos dos serviços de international mobile roaming (IMR). Os signatários concordaram que podem tomar medidas para promover a concorrência nos serviços de IMR para celular e facilitar o uso de alternativas ao roaming. No USMCA, esses serviços também foram contemplados. Os membros concordaram que vão promover a cooperação sobre tarifas, taxas e regulamentaçóes para os serviços de IMR. No art. 18.4, consta que não se proibirá qualquer fornecedor de serviços públicos de telecomunicaçôes de celebrar contratos para o fornecimento de serviços de roaming, "incluindo um contrato para fornecer serviços de roaming a dispositivos que náo estejam limitados a uma presença transitória no território de uma parte" (United States of America, 2018, art. 18.4, tradução nossa).

Devido ao crescente uso de dados e de centros de computação em nuvem, o capítulo correspondente ao comércio eletrônico impacta diretamente os interesses da indústria americana de telecomunicaçôes, particularmente no que diz respeito à circulação de dados através de fronteiras. Os signatários concordaram em garantir às empresas o direito de escolha da localização dos centros de processamento de dados, de forma independente da localização das respectivas subsidiárias e/ou filiais. Assim como as instituiçóes financeiras, as operadoras de telecomunicaçóes também esperam obter vantagens decorrentes da redução dos custos e das eficiências das redes derivadas do gerenciamento centralizado das operaçóes de processamento de dados (Signoret e Bloodgood, 2016).

Tal qual no capítulo relativo a serviços financeiros, determinou-se a criação de uma Comissão de Telecomunicaçôes, destinada nesse caso "a rever e monitorar as relações de telecomunicaçóes entre os três países envolvidos no acordo" (United States of America, 2018, art. 18.27, tradução nossa). Na prática, este será um órgão que monitorará todo tipo de medida governamental que possa eventualmente impactar as iniciativas das empresas estrangeiras. Garantir o acesso e a utilização dos serviços e infraestruturas de telecomunicaçôes é a principal responsabilidade da tal comissão, mas certamente monitorará outras tantas - ela deve se configurar um canal a ser utilizado pelas empresas, principalmente as americanas. Conforme já haviam sublinhado Signoret e Bloodgood (2016, p. 391, tradução nossa), referindo-se ao TPP, "as disposições do capítulo também permitirão que as 
empresas de telecomunicações dos Estados Unidos adotem ações de fiscalização contra empresas estatais que se envolvam em medidas discriminatórias".

No caso do México, as empresas estrangeiras serão as fiscalizadoras da implementação de reformas econômicas. Note-se que o acordo tem o efeito de vincular o México às reformas constitucionais empreendidas em 2013 no setor de telecomunicaçôes, garantindo o cumprimento de obrigaçóes de acesso e interconexão, a independência política da agência interna de regulação e o tratamento nacional nas taxas de recompra de serviços de telecomunicaçóes.

\subsubsection{Serviços digitais}

O NAFTA foi negociado e entrou em vigor no início da era da internet, ou seja, antes da ascensão do comércio digital. Compreensivelmente, não dispôs sobre barreiras, regras e disciplinas relativas a produtos digitais.

De modo diferente, no USMCA, a importância crescente do comércio digital garantiu um capítulo específico, o 19, como já havia ocorrido no TPP. Segundo um estudo de 2016 da empresa Accenture, ${ }^{20}$ aproximadamente $22 \%$ da produçáo econômica global pode ser atribuída diretamente ao comércio digital, e espera-se que a aplicação continuada de tecnologias digitais emergentes - como computação em nuvem, análise de dados, impressão em 3D e Internet das Coisas (Internet of Things - IoT) - aumentará o produto interno bruto (PIB) global em mais US\$ 2 trilhões até 2020 (Knickrehm, Berthon e Daugherty, 2016).

Afinal, o que são serviços digitais? No entendimento dos signatários do USMCA, havia de se definir produtos digitais, e dentro dessa categoria foram compreendidos os seguintes: programa de computador, texto, vídeo, imagem, gravação de som ou outro produto codificado digitalmente, produzido para a venda ou a distribuição comercial e que pode ser transmitido eletronicamente (United States of America, 2018).

Conforme corretamente apontam os juristas, a definição é ampla o suficiente para abranger diferentes serviços. Pode abarcar, por exemplo, serviços populares de streaming de música, serviços de vídeo por assinatura, plataformas de conteúdo geradas por usuários e varejistas de e-books etc. (Prescott, Kerr-Wilson e Dunbar, 2018).

Outras definições que receberam destaques no acordo são: serviço interativo de computador e provedor de conteúdo de informaçóes. O primeiro refere-se a "um serviço que permite acesso eletrônico a um servidor de computador e inclui empresas de cabo e telecomunicaçóes que fornecem serviços de acesso à internet". O segundo refere-se a "uma entidade que cria ou desenvolve informações fornecidas pela internet, incluindo serviços de vídeo e música on-line” (United States of America, 2018, tradução nossa). 
Entre as principais disposiçóes do capítulo sobre o comércio digital proposto pelo USMCA, destacam-se as seguintes.

1) Garantir um tratamento não discriminatório dos produtos digitais.

2) Assegurar a transferência transfronteiriça de fluxos de dados se para fins comerciais e proibir requisitos de localizaçáo e de uso de instalaçóes de computação como condição para a realização de negócios.

3) Proibir requisitos para a divulgação ou transferência de código-fonte ou algoritmo como condição para o acesso a mercados, com exceçóes.

4) Proibir direitos alfandegários, taxas ou outros encargos relacionados à importação ou exportação de produtos transmitidos eletronicamente entre pessoas de qualquer dos membros (com isso, proibiram-se impostos sobre música e e-books, por exemplo).

5) Exigir que os membros possuam leis de proteção ao consumidor em transaçôes eletrônicas.

6) Proteger a informação pessoal e o enquadramento legal da privacidade.

7) Promover a cooperação em segurança cibernética, estratégias baseadas no risco e padróes baseados em consenso sobre a regulação prescritiva no combate a riscos e eventos de segurança cibernética.

8) Zelar pela importância da promoção dos serviços interativos de computador.

9) Promover a publicação de dados governamentais abertos, em formato legível, por máquina, para o uso público.

É válido observar que, enquanto a maioria das obrigaçôes relacionadas ao comércio digital é encontrada no capítulo 19, existem disposiçōes também relevantes em outros capítulos, como em serviços financeiros (abordados na subseção 3.2.1 deste texto), em telecomunicações (subseçâo 3.2.2), em propriedade intelectual e em outros.

Há de se ressaltar também que compras governamentais e disposiçóes sobre dados mantidos ou processados pelos governos dos respectivos países ficaram de fora do acordo. Esta última exceção reflete fundamentalmente as preferências dos negociadores canadenses, cujo governo exige que os dados eletrônicos (considerados sensíveis) sob seu controle sejam armazenados em uma instalação de computação aprovada por ele próprio ou sejam localizados no território canadense.

Cada uma das disposiçóes do capítulo sobre o comércio digital propostas pelo USMCA mereceria uma discussão a respeito dos interesses em jogo, os impactos 
para as partes envolvidas e as consequências para a governança internacional sobre o tema. Entretanto, para não alongar e extrapolar o espaço aqui disponível, deve-se deixar isso para uma outra oportunidade. Por ora, é importante que se concentre nas disposiçóes que envolvem garantias de transferência de dados e de proteção sobre a informação pessoal e a privacidade.

\section{Regulamentação digital: fluxo de dados e questões de privacidade}

Comparativamente à União Europeia, os Estados Unidos possuem uma regulamentação mais flexível relativa às questôes digitais, sobretudo no que diz respeito ao livre fluxo de dados e a questóes de privacidade. Isso influenciou predominantemente as disposiçóes legais presentes no USMCA, o qual prevê que "nenhuma parte proibirá ou restringirá a transferência de informaçóes transfronteiriças, incluindo informações pessoais, por meios eletrônicos, se esta atividade for para a condução dos negócios de uma pessoa [fornecedor] coberta" (United States of America, 2018, tradução nossa).

Embora tal questão já tivesse sido contemplada no TPP, no USMCA ela foi objeto de maior assertividade. O compromisso dos membros torna-se "impedir" uma medida entendida como negativa. Como notou a Information Technology and Innovation Foundation (ITIF), "elas [disposiçóes legais] se concentram na prevenção ou na remoção da barreira comercial” (ITIF, 2018, p. 5, tradução nossa), enquanto no TPP o compromisso se enquadra mais em uma "afirmação positiva" e menos em uma "obrigaçáo".

Para a ITIF, a questão semântica, não obstante, é a menor das diferenças entre os dois acordos. O mais importante é que o USMCA altera substancialmente as provisóes, limitando as medidas de exceção. A cláusula diz que "nenhuma parte exigirá que uma pessoa [fornecedora] coberta [abarcada pelo acordo] use ou localize instalações de computação no território dessa parte como condição para conduzir negócios" (United States of America, 2018, tradução nossa) - após essa cláusula, não se verificam subseçoóes prevendo condicionalidades. Diferente regra havia se estabelecido no TPP, prevendo que um membro possa adotar medidas inconsistentes com o parágrafo 2 - relativo à não exigência de uso ou de localização das instalaçóes de computação - com o objetivo de política pública.

Nada no presente artigo impedirá uma parte de adotar ou manter medidas incompatíveis com o parágrafo 2 para alcançar um objetivo legítimo de política pública, desde que a medida: i) não seja aplicada de maneira a constituir discriminaçáo injustificável ou arbitrariedade, uma restriçáo disfarçada ao comércio; e ii) não imponha restrições ao uso ou localização de instalações de computação maiores do que o necessário para alcançar o objetivo (tradução nossa). ${ }^{21}$

21. Disponivel em: <https://ustr.gov/trade-agreements/free-trade-agreements/trans-pacific-partnership/tpp-full-text>. 
Para os defensores da liberalização do comércio digital, como a ITIF e outros agentes econômicos, em tal brecha caberia uma infinidade de justificativas, e isso desfiguraria o caráter de liberdade de mercado. As críticas dos agentes econômicos recaem, por exemplo, sobre o Vietná, que apresenta motivos de segurança nacional e de interesse público junto à Organização Mundial do Comércio (OMC) para justificar os requisitos de localização de dados no âmbito da sua nova política de segurança cibernética. Também é alvo de críticas a União Europeia, que precisa manter seus APCs e os acordos multilaterais em harmonia com suas instituiçôes internas.

$\mathrm{Na}$ concepção desses defensores da liberalização, esse é um problema iminente para o comércio digital global, na medida em que "alguns países consideram a localização de dados uma ferramenta legítima de política pública, mas não explicam por que é necessária e por que políticas alternativas não são usadas" (ITIF, 2018, p. 5, tradução nossa).

A questão, conforme já tivemos a oportunidade de manifestar, é que não se trata de comum argumentaçâo relativa às vantagens ou desvantagens econômicas da liberalização. A pressão pela transferência indiscriminada de dados suscita questôes fundamentais para a garantia dos direitos individuais e a integridade da democracia.

\section{AS REGRAS SOBRE INVESTIMENTOS NO NAFTA E NO USMCA}

No que diz respeito às regras sobre investimentos contidas em acordos comerciais internacionais, o NAFTA inaugurou um padrão que se tornou referência nas relaçóes comerciais conduzidas pelos Estados Unidos.

Concretamente, removeu barreiras significativas de investimento, como aquelas traduzidas nos requisitos de desempenho, e fundamentalmente assegurou aos investidores proteçôes extraordinárias, fornecendo um mecanismo para a resolução de disputas, que envolvia de um lado a figura do investidor e de outro a do Estado.

No entendimento dos defensores do padrão introduzido pelo NAFTA e dos acordos bilaterais de investimentos (ABIs) dos Estados Unidos, tais modelos especificaram disposiçóes, incluindo compromissos para afirmar com mais clareza o direito do governo de regulamentar os objetivos ambientais, de saúde e outros objetivos de política pública. Os governos se viram, entretanto, temerariamente desafiados nas suas tomadas de decisão.

\subsection{Mecanismo de solução de disputas investidor-Estado}

As provisões propostas do USMCA, em geral, harmonizam-se com as do NAFTA, com exceção do conjunto de cláusulas relativas ao sistema de solução 
de controvérsias, ou seja, o mecanismo de solução de disputas investidor-Estado (investor-State dispute settlement-ISDS).

Um dos principais objetivos dos negociadores americanos nas negociaçóes para a conformação de APCs de um modo geral é implementar regras sobre investimentos, o que cobre tanto o setor de serviços como outros setores da economia, a exemplo da manufatura, da mineração e da agricultura.

O mecanismo ISDS, que faz parte do conjunto de regras sobre investimentos, tornou-se emblemático porque permite que investidores nacionais (entes privados) de um Estado signatário apresentem reclamaçóes contra um outro Estado signatário, perante um tribunal arbitral internacional. ${ }^{22}$ Interessa notar que o ISDS dá ao reclamante - no caso, ao investidor - o direito de iniciar um processo judicial contra o Estado, independentemente de os recursos pelas instâncias judiciárias estatais terem sido esgotados. Esse poder explica o fato de tal mecanismo ser associado à justiça privada.

O ISDS passou a ser usado também nos acordos comerciais, uma vez que os negociadores americanos convenceram seus interlocutores no NAFTA a aceitar a inserção de regras sobre investimentos em um acordo preferencial de comércio. O ISDS vinha sendo usado ao longo de décadas nos ABIs, mas até então não havia sido incluído nos APCs.

Nas negociações do GATS também estava sendo adotado um mecanismo de solução de disputas, porém, como as discussôes sobre as regras de investimentos não estavam resultando em acordo, a configuração do mecanismo acabou sendo substancialmente diferente. ${ }^{23}$

Os negociadores americanos, alinhados com as preferências dos agentes econômicos e também com os negociadores canadenses, argumentavam que o modelo Estado-Estado já havia apresentado problemas no passado: o custo com o uso desgastante de recursos diplomáticos e a demora na solução das controvérsias. Sendo assim, o ISDS seria ideal para proteger os investidores contra tratamentos discriminatórios e expropriações indébitas e para facilitar a resolução de disputas de investimento.

22. Esse tipo de tribunal é ad hoc, formado por três árbitros: um indicado pelo reclamante (no caso, o investidor); outro indicado pelo governo envolvido; e um terceiro indicado por ambas as partes em disputa ou por ambos os árbitros já indicados - ou ainda por alguma autoridade. Ao final do processo, o tribunal tem poderes para proferir uma sentença, a qual deve ser reconhecida pelas partes, ou seja, não pode ser desafiada, exceto se houver algum vício processual. 0 processo todo corre em segredo e os árbitros não precisam ser juízes de formação ou de exerćício, nem ser eleitos democraticamente ou apontados, e não estão sujeitos a regras rigorosas de conflito de interesses.

23. A propósito, o acordo sobre as regras de investimentos - Trade-Related Investment Measures (TRIMs) -, que resultou das negociações da Rodada Uruguai, estipula, em seu primeiro artigo, que o referido acordo se aplica às regras de investimentos relacionadas ao comércio de bens manufaturados apenas. Portanto, as regras estipuladas no TRIMs não se aplicam a serviços; no GATS, os sujeitos legítimos das respectivas ações arbitrais são exclusivamente os Estados - Estado-Estado. Nesse caso, o investidor, ao tentar dirimir um conflito envolvendo o Estado hospedeiro do investimento, terá de apelar para o seu próprio governo e solicitar-lhe que impetre a ação, acolhendo sua reivindicação. 
Os argumentos dos negociadores americanos tiveram um apelo junto aos canadenses, porque apontavam que o México possuía um histórico de hostilidade em relação aos investidores estrangeiros. A Revolução Mexicana, na primeira metade do século XX, e a nacionalização do petróleo e de algumas outras indústrias teriam sido alimentadas pelo ressentimento contra os investimentos externos. Tais negociadores lembravam ainda que, pouco antes de deixar o governo em 1982, o presidente Lopez Portilho havia nacionalizado os bancos, causando fuga de capital e redução no influxo de investimento externo. Ademais, destacavam que, na década de 1980, o governo mexicano se recusou a aderir ao Acordo Geral sobre Tarifas e Comércio (General Agreement on Tariffs and Trade - GATT), temendo que as regras do regime interferissem nas políticas industriais do país (McKinney, 2015, p. 4).

Esse histórico tendia a vestir de legitimidade a demanda dos americanos e, indiretamente, a dos canadenses. Em contrapartida, os negociadores mexicanos não podiam esquecer que as iniciativas do governo, visando atrair investimentos japoneses e europeus, haviam fracassado. Cabe lembrar que os europeus ocidentais, na esteira do colapso da União Soviética, estavam sobretudo interessados nas oportunidades e nos desafios oferecidos pelo leste da Europa. Sendo assim, a decisão mais acertada, tendo em vista a meta de atrair o capital estrangeiro, seria sinalizar que as reformas econômicas mexicanas eram genuínas e permanentes por meio do NAFTA.

Quando os negociadores americanos chegaram à mesa de negociação do USMCA, precisaram levar em conta o caloroso debate envolvendo a questão do ISDS, que, depois de duas décadas presente nos acordos inspirados pelo NAFTA, encontrou forte resistência.

De um lado, os defensores argumentavam que o ISDS seria importante para proteger os investidores de tratamento discriminatório, ao mesmo tempo que não impediria os governos de regular em nome do interesse público, com claras exceçóes para essas açóes, bem como para a segurança nacional e por razóes prudenciais. O American Petroleum Institute (API), por exemplo, afirmou que fortes disposiçóes do ISDS protegeriam os interesses das empresas americanas. Além disso, reiteradamente, os defensores exibem o fato de que os Estados Unidos, até o momento, nunca perderam uma queixa sob o ISDS apresentada contra o país (Bradley, 2018).

De outro lado, os críticos argumentavam que as empresas usariam, sim, o ISDS para restringir a capacidade dos governos de regular em nome do interesse público, especialmente em questóes ambientais e de saúde, levando ao "congelamento regulatório", mesmo que um resultado do ISDS não fosse pontualmente favorável a uma determinada empresa (Villarreal e Fergusson, 2019). 
A crítica influenciou significativamente os resultados da negociação entre os signatários do USMCA. Em termos concretos, o ISDS náo consta dos compromissos assumidos em nome do Canadá. O anexo 14-D, que detalha tal cláusula, denomina-se Mexico-United States investment disputes (United States of America, 2018). Significa que investidores americanos e mexicanos não podem levar reivindicaçóes à arbitragem internacional no âmbito do USMCA contra o Canadá, tampouco os investidores canadenses podem fazer o mesmo contra os Estados Unidos ou o México. Note-se que Canadá e México mantêm o ISDS entre si por meio do Acordo Abrangente e Progressivo para a Parceria Transpacífica (Comprehensive and Progressive Agreement for Trans-Pacific Partnership - CPTPP).

No que se refere aos compromissos assumidos entre Estados Unidos e México, o ISDS foi inserido no USMCA, mas não de forma universal, conforme o foi no NAFTA. Nos termos do novo acordo (anexo 14-E), o uso do ISDS é amplamente permitido para investidores que possuem contrato com o governo anfitrião nos seguintes setores: petróleo e gás, geração de energia, telecomunicações, transporte e infraestrutura (United States of America, 2018). O argumento que predominou a favor da manutenção do ISDS nesses casos diz que se pretende proteger os investidores em indústrias altamente regulamentadas, cujos investimentos podem ser afetados pela presença de empresas estatais no mercado.

Nos demais setores, o ISDS pode ser empregado desde que o demandante tenha primeiramente esgotado os recursos judiciais nacionais.

\section{CONCLUSÃO}

O desenvolvimento dos regimes internacionais atinentes ao comércio de serviços, particularmente serviços financeiros, telecomunicaçóes e serviços digitais, e às regras de investimentos, com base na comparação entre o NAFTA e o USMCA, foi o foco deste artigo.

Em linhas gerais, o estudo ajudou a mostrar que o novo acordo, com todas as mudanças introduzidas, não rompe com a política setorial do Estado americano. O novo acordo serviu para legitimar, junto ao Canadá e ao México, as mudanças que os Estados Unidos introduziram nas últimas décadas e já vinham apresentando em diferentes fóruns. Logo, indica que há, por trás dos termos e condiçôes apresentados no USMCA, um consenso bipartidário.

Durante décadas após a Segunda Guerra Mundial, os Estados Unidos foram indiscutivelmente os maiores defensores da liberalização do comércio que ocorreu. $\mathrm{O}$ efeito distributivo dos acordos comerciais internacionais, entretanto, não poupou o país norte-americano. 
Como previam algumas análises, por parte das comunidades que sofreram mais prejuízos que ganhos com a internacionalização econômica, uma reação política estava fadada a emergir. O que Trump fez foi não apenas perceber a iminência dessa reação, mas responder de imediato, apresentando, ainda em campanha eleitoral, uma política comercial que supostamente responderia a essa crise.

Com uma abordagem assertiva e conflituosa, impulsionada por uma agenda tida como nacionalista, a referida administração arrastou os negociadores mexicanos e canadenses para rever os termos e condiçóes estabelecidos no NAFTA, no início da década de 1990, aplicando sem parcimônia as "táticas trumpianas" de negociação.

Primeiro, os negociadores americanos atiraram sobre a mesa as queixas, principalmente os deficit comerciais, que seriam um sinal de fraqueza e uma indicação de que os acordos comerciais são falhos e injustos. As empresas e os trabalhadores mexicanos, com práticas de baixos custos e salários, estariam desviando o comércio em desvantagem dos Estados Unidos. Sendo assim, a liberalização do setor de serviços deveria ser ainda maior que aquela acordada no NAFTA, principalmente a liberalização do comércio transfronteiriço.

Em seguida, insultaram seus interlocutores, inclusive os canadenses, ao adotar uma dinâmica de negociação bilateral, escolhendo primeiro os mexicanos para impor suas condiçóes. Embora tenham encontrado resistência interna democratas e republicanos avisaram à administração que se oporiam a qualquer acordo que deixasse o Canadá de fora -, os negociadores americanos partiram para cima dos canadenses, que acabaram fazendo concessóes.

Depois, os negociadores americanos indicaram que, na verdade, estavam comprometidos com o acordo. Conforme foi mostrado aqui, apesar da caracterização do NAFTA pelo presidente Trump como o pior acordo comercial já assinado pelos Estados Unidos, assim como suas críticas mordazes às equipes de negociadores das administraçóes anteriores, os termos e condiçôes acordados no USMCA não configuram uma desconstrução ou algo erguido de fundamentos elementares. Há mudanças importantes certamente, em comparação ao que fora estabelecido no NAFTA, mas não se pode tomá-las como genuínas. Na verdade, verifica-se que há um grau alto de similaridades com os termos e condiçóes que haviam sido acordados no TPP.

Sobre os serviços financeiros, conforme já havia sido estabelecido no TPP, o USMCA afirma que nenhum membro pode impedir que sejam transferidas informaçóes para dentro e fora do território onde operadores estejam desempenhando suas atividades quando as informaçôes estiverem vinculadas ao escopo de sua licença. Além disso, foram introduzidas disposiçóes relativas ao uso e à localização de instalaçóes de computação por instituiçóes financeiras. 
Os membros não podem exigir que os operadores localizem instalaçôes de computação em seu território como condição para conduzir os negócios ali.

Tais disposiçóes são de grande importância para os negociadores americanos. Revelam, pois, um dos principais emblemas do padrão estabelecido pelos Estados Unidos em contraposição ao padrão europeu. Como já havia ocorrido no NAFTA, o México, principalmente, desempenhou papel fundamental ao ajudar a legitimar internacionalmente o padrão americano.

Além disso, assim como no NAFTA, o México foi essencial para garantir o avanço da liberalização do comércio de serviços financeiros, inclusive novos serviços que venham a ser comercializados no futuro. O USMCA reza que os signatários não podem adotar medidas que limitem o número de instituiçóes financeiras, fornecedores de serviços financeiros transfronteiriços, operaçôes de serviços financeiros ou número de pessoas físicas empregadas - tampouco podem estabelecer limites sobre o valor total de transaçóes ou dos ativos de serviços financeiros.

No tocante a serviços de telecomunicaçôes, também muitas das disposiçôes já haviam sido negociadas no TPP. O capítulo 18 do USMCA prevê uma série de regras que se aplicam a quaisquer medidas relativas: $i$ ) ao acesso e à utilizaçáo de redes ou serviços públicos de telecomunicaçóes; ii) a obrigaçóes de fornecedores de serviços públicos de telecomunicaçóes; e iii) à prestação de serviços caracterizados como não essenciais - todos os que vão além dos serviços-padrão de telefonia, como chamadas de voz e transmissão de mensagens por fac-símile (telecopying, telefax). Sobre estes, frisou-se que o tratamento dispensado aos seus provedores não deve ser o mesmo dispensado aos provedores de serviços públicos de telecomunicaçôes.

O ponto tido como extraordinário no conjunto de regras do capítulo em referência é o que versa sobre o uso de redes públicas de telecomunicaçôes para transferir informaçóes no território de cada signatário e através de suas fronteiras, bem como para o acesso a informaçóes em bancos de dados no território de qualquer dos signatários.

Como pode-se verificar neste estudo, mais uma vez o México aceitou vincular suas reformas constitucionais empreendidas em 2013 no setor de telecomunicações - garantindo as obrigações de acesso e interconexão, a independência política da agência reguladora e o tratamento nacional nas taxas de recompra de serviços de telecomunicaçóes - a um acordo internacional com poder de enforcement. Os negociadores americanos cercaram-se de diferentes estratégias de busca da conformidade e sançóes. Sob o acordo, o México, em especial, está sujeito a penalidades severas se infringir as correspondentes regras.

Serviços digitais também foram objeto de regras estabelecidas no USMCA e vão contribuir significativamente para legitimar as regras de preferência dos Estados Unidos que tendem a contrapor outros padróes. 
Não causou surpresa a inserção de um capítulo abrangendo regras sobre tais tipos de serviços em razão da importância que ganharam com o advento da internet. O que chama a atenção, entretanto, é o fato de os signatários, especialmente os negociadores canadenses, terem concordado com a definiçấo abrangente dos chamados "produtos digitais". Significa que inúmeros serviços podem ser compreendidos e, na prática, as regulamentaçóes culturais canadenses podem acabar sendo impactadas. Se assim for, os negociadores americanos terão tangenciado a resistência histórica de seus interlocutores canadenses, que mantêm os serviços audiovisuais fora do escopo das negociações comerciais há anos.

Ao passo que o desenvolvimento dos regimes internacionais relativos ao comércio de serviços, medido com a comparação entre as regras do NAFTA e do USMCA, pode ser interpretado como uma mudança incremental à medida que as regras se reproduzem por adaptaçấo sem rompimento com o padrão anterior, $\mathrm{o}$ desenvolvimento dos regimes internacionais relativos a regras sobre investimentos contidas nesses acordos comerciais introduz uma mudança a mais.

A principal diferença entre o NAFTA e o USMCA refere-se a regras sobre investimentos, sobretudo o sistema ISDS, atinente à resolução de conflitos, baseado na arbitragem internacional, o qual coloca em disputa direta investidor e Estado.

No USMCA, o ISDS não está previsto como um sistema de resolução de controvérsias entre partes dos Estados Unidos e do Canadá - o que póe fim, portanto, à permissão prevista no NAFTA para que investidores processassem os Estados por alegadas práticas discriminatórias. Entretanto, entre partes dos Estados Unidos e do México, o USMCA garante o uso do ISDS para dirimir conflitos relativos a investimentos ligados aos setores de gás e petróleo e de infraestrutura.

Tais mudanças, quando o NAFTA expirar, podem ser entendidas como um reposicionamento institucional, que se caracteriza como uma transformaçáo gradual.

Por fim, seguindo a lógica das "táticas trumpianas" de negociaçâo, os negociadores americanos, capitaneados pelo próprio Trump, reivindicaram para si um tremendo sucesso. Nesse caso, há de se ponderar. Abstraindo o fato de que boa parte do que havia sido estabelecido no USMCA já existia no TPP, o acordo não deixa de ser uma vitória para os Estados Unidos.

\section{REFERÊNCIAS}

BECK, R. The volatility of capital flows to emerging markets and financial services trade. Center for Financial Studies, Frankfurt, n. 2000/11, 2000.

BLATCHFORD, A. Here's what Canada wants from the NAFTA negotiations. Global News, 14 Aug. 2017. Disponível em: <https://bit.ly/2nSTVKU>. Acesso em: 5 jul. 2018. 
BRADLEY, B. Panelists detail limited ISDS in USMCA. American Shipper, 2 Nov. 2018. Disponível em: <https://www.freightwaves.com/news/panelistsdetail-limited-isds-in-usmca>. Acesso em: 19 fev. 2019.

CAMERON, M. A.; TOMLIN, B. W. The making of NAFTA: how the deal was done. Ithaca, United States: Cornell University Press, 2000.

COOLBEN, A. The birth of NAFTA. Association for Diplomatic Studies and Training, 8 Aug. 2014. Disponível em: <https://bit.ly/1NTmYPA>. Acesso em: nov. 2015.

COOPER, W. H.; NELSON, R. M. U.S. foreign trade in services: trends and U.S. policy challenges. Washington: CRS, 2014. Disponível em <https:// digitalcommons.ilr.cornell.edu/cgi/viewcontent.cgi? referer=https:/www.google. com/\&httpsredir=1\&article=2286\&context=key_workplace $>$. Acesso em: jul. 2014. CRUZ, S. C. V. Estados e mercados: os Estados Unidos e o sistema multilateral de comércio. São Paulo: Editora Unesp, 2017.

DRAKE, W. J.; NICOLAÏDIS, K. Ideas, interests, and institutionalization: "trade in services" and the Uruguay Round. International Organization, v. 46, n. 1, p. 37-100, 1992.

ENCISO, J. A. G.; CASTRO, M. B. G. O México no tratado de livre comércio México-Estados Unidos-Canadá: uma nota introdutória. Indicadores Econômicos FEE, v. 20, n. 1, 1992.

FISCHER, R.; URY, W.; PATTON, B. Como chegar ao sim: a negociação de acordos sem concessôes. Rio de Janeiro: Imago, 2005.

HUFBAUER, G. C.; GLOBERMAN, S. The United States-Mexico-Canada Agreement: overview and outlook. Fraser Research Bulletin, Nov. 2018. Disponível em: <https://bit.ly/317q1SU>. Acesso em: 15 fev. 2019.

ITIF - INFORMATION TECHNOLOGY AND INNOVATION FOUNDATION. Investigation no. TPA-105-003, United States-Mexico-Canada Agreement: likely impact on the U.S. economy and on specific industry sectors. Washington: ITIF, 17 Dec. 2018. Disponível em: <https://bit.ly/2OLrEU5>. Acesso em: 18 jan. 2019.

KNICKREHM, M.; BERTHON, B.; DAUGHERTY, P. Digital disruption: the growth multiplier. Dublin: Accenture, 2016. Disponível em: <https://accntu. re/2YNTBu6>. Acesso em: 10 mar. 2019.

LEDERMAN, D.; MALONEY, W. F.; SERVÉN, L. Lessons from NAFTA for Latin America and the Caribbean. Washington: Stanford University Press; World Bank, 2005. 
MACE, G.; BÉLANGER, L. Convergence or divergence effects? NAFTA and state preferences towards the FTAA. In: MACE, G. (Ed.). Regionalism and the State: NAFTA and foreign policy convergence. Burlington, New Jersey: Ashgate, 2007.

MATTHEWS, R. La sociedad de Estados Unidos y significado del síndrome Trump. In: MEDINA, F. M. La convivencia amenazada: anhelos y radicalismos. Zaragoza, España: Mira Editores; Fundación SIP, 2018.

MAZZA, J. Don't disturb the neighbors: the United States and democracy in Mexico, 1980-1995. New York: Routledge, 2001.

MCKINNEY, J. A. Investor-State dispute resolution as an issue in transatlantic trade negotiations: lessons from NAFTA. Jean Monnet/Robert Schuman Paper Series, v. 15, n. 3, Aug. 2015.

PARTINGTON, R. Nafta: what is it and why is Trump trying to renegotiate? The Guardian, 30 Aug. 2018. Disponível em: <https://bit.ly/2KmEN1K>. Acesso em: 12 jan. 2019.

PENAA, A. de la. Mexican government announces key positions for upcoming renegotiation of NAFTA. Haynesboone, 3 Aug. 2017. Disponível em: <https:// bit.ly/2M6gDue>. Acesso em: 10 ago. 2018.

PIERSON, P. Increasing returns, path dependence, and the study of politics. American Political Science Review, v. 94, n. 2, p. 251-267, June 2000.

PRESCOTT, S. M.; KERR-WILSON, G.; DUNBAR, L. J. E. USMCA impact on communications industries. Fasken, 11 Oct. 2018. Disponível em: <https:// bit.ly/2TeAmcg>. Acesso em: 2 mar. 2019.

RAUHALA, E. Trump calls USMCA “a groundbreaking achievement”. But tariffs have turned ties with Canada cold. The Washington Post, 30 Nov. 2018. Disponível em: <https://wapo.st/2yKDzH5>. Acesso em: 10 jan. 2019.

ROSS, S. With new trade deal, Canada avoids a doomsday scenario. But is it a win? The Washington Post, 1 Oct. 2018. Disponível em: <https://www. washingtonpost.com/world/the_americas/with-new-trade-deal-canada-avoidsa-doomsday-scenario-but-is-it-a-win/2018/10/01/304d7968-c5a0-11e8-9c0f2ffaf6d422aa_story.html> Acesso em: 10 jan. 2019.

SCHNEIDER-PETSINGER, M. Trade policy under president Trump: implications for the US and the world. Chatham House, Nov. 2017. Disponível em: <https://bit.ly/2GROEuc>. Acesso em: 28 jun. 2018.

SCHOTT, J. J.; BRADFORD, S. C.; MOLL, T. Negotiating the Korea-United States free trade agreement. Policy Briefs in Internacional Economics, n. PB06-4, June 2006. Disponível em: <https://bit.ly/2YS9znh>. Acesso em: mar. 2016. 
SIGNORET, J.; BLOODGOOD, L. Trans-Pacific Partnership agreement: likely impact on the U.S. economy and on specific industry sectors. Washington: USITC, May 2016. Disponível em: <https://bit.ly/1TZJtoh>. Acesso em: mar. 2016.

STARGARDTER, G.; LAWDER, D. Mexico says will not renegotiate NAFTA under pressure, but makes new offer. Reuters, 24 May 2018. Disponível em: $<$ https://reut.rs/2YRCJmu>. Acesso em: 15 mar. 2019.

STEINBERG, R. H. The North American Free Trade Agreement: a legal analysis of effects and opportunities. Ohio: Business Laws, Apr. 1994. Disponível em: $<$ https://brie.berkeley.edu/sites/default/files/wp_65.pdf>. Acesso em: dez. 2015.

TUSSIE, D. The Uruguay Round and the trading system in the balance: dilemmas for developing countries. In: AGOSIN, M. B.; TUSSIE, D. (Ed.). Trade and growth: new dilemmas in trade policy. New York: St. Martin's Press, 1993.

UNITED STATES OF AMERICA. Office of the United States Trade Representative. Agreement between the United States of America, the United Mexican States, and Canada. Washington: USTR, 2018. Disponível em: $<$ https://ustr.gov/trade-agreements/free-trade-agreements/united-states-mexicocanada-agreement/agreement-between>. Acesso em: 12 jan. 2019.

VILLARREAL, M. A. NAFTA and the Mexican economy. Congressional Research Service, 3 June 2010. Disponível em: <https://bit.ly/2ETy7Y1>. Acesso em: 12 fev. 2019.

VILLARREAL, M. A.; FERGUSSON, I. F. NAFTA renegotiation and the proposed United States-Mexico-Canada Agreement (USMCA). Congressional Research Service, 26 Feb. 2019. Disponível em: <https://bit.ly/2vufu5g >.

WTO - WORLD TRADE ORGANIZATION. General agreement on trade in services: LT/UR/A-1B/S/1. Switzerland: WTO, 15 Apr. 1994. Disponível em: <https://docs.wto.org/dol2fe/Pages/FE_Search/FE_S_S009-DP. aspx?language $=E \&$ CatalogueIdList=57066 $>$. Acesso em: 18 jul. 2009.

\section{BIBLIOGRAFIA COMPLEMENTAR}

AGGARWAL, V. K. The political economy of service sector negotiations in the Uruguay Round. The Fletcher Forum, v. 16, n. 1, p. 35-54, 1992.

BLACK, S. K. Telecommunications law in the internet age. San Francisco: Morgan Kaufmann, 2002.

BOSCARIOL, J. W. et al. NAFTA renegotiation monitor: a status report on the North American free trade agreement renegotiation. Toronto: Haynesboone; McCarthy Tétrault, 2018. Disponível em: <https://bit.ly/2KnGSKW>. Acesso em: 5 jul. 2018. 
EBERHARDT, P.; REDLIN, B.; TOUBEAU, C. Trading away democracy: how CETA's investor protection rules threaten the public good in Canada and the EU. The Netherlands: TNI, 2014. Disponível em: <https://bit.ly/31rArfA>. Acesso em: set. 2016.

EUROPEAN COMMISSION. Comprehensive Economic and Trade Agreement (CETA). Official Journal of the European Union, Feb. 2016. Disponível em: <https://bit.ly/1ScSoGS>. Acesso em: set. 2016.

FEFER, R. F. U.S. trade in services: trends and policy issues. Congressional Research Service, 4 Feb. 2016. Disponível em: <https://nationalaglawcenter. org/wp-content/uploads//assets/crs/R43291.pdf>. Acesso em: jul. 2017.

FEKETEKUTY, G. International trade in services: an overview and blueprint for negotiations. Cambridge, United States: Ballinger Pub, 1988.

. Trade in services: bringing services into the multilateral trading system. In: BHAGWATI, J. N.; HIRSCH, M. (Ed.). The Uruguay Round and beyond: essays in honor of Arthur Dunkel. Berlin: Springer, 1998.

FRITZ, T. Analysis and evaluation of the Comprehensive Economic and Trade Agreement (CETA) between the EU and Canada. Berlin: Hans Böckler Stiftung, 2015. Disponível em: <https://thomas-fritz.org/english/analysis-andevaluation-of-the-comprehensive-economic-and-trade-agreement-ceta-betweenthe-eu-and-canada>. Acesso em: out. 2016.

HALL, P. A. Preference formation as a political process: the case of monetary union in Europe. In: KATZNELSON, I.; WEINGAST, B. R. (Ed.). Preferences and situations: points of intersection between historical and rational choice institucionalism. New York: Russel Sage Foundation, 2005.

HÜBNER, K.; BALIK, T.; DEMAN, A-S. CETA: the making of the Comprehensive Economic and Trade Agreement between Canada and the EU. Paris: Ifri, 2016. Disponível em: <https://bit.ly/2g3eikG>.

HUFBAUER, G. C. Could a president Trump shackle imports? In: NOLAND, M. et al. Assessing trade agendas in the US presidential campaign. Washington: PIIE, 2016. Disponível em: <https://bit.ly/2cCfqrf>. Acesso em: 16 jun. 2017.

ITAC 8 - INDUSTRY TRADE ADVISORY COMMITTEE FOR INFORMATION AND COMMUNICATIONS TECHNOLOGIES, SERVICES AND ELECTRONIC COMMERCE. Report. Washington: ITAC 8, 3 Dec. 2015. Disponível em: <https://bit. ly/2TKxdzb>.

KELSEY, J. Serving whose interests? The political economy of trade in services agreements. Oxon; New York: Routledge-Cavendish, 2008. 
LOW,P.;MATTOO,A.Isthereabetterway?Alternativeapproachestoliberalization under the GATS. Washington: World Bank, 2001. Disponível em: <https://pdfs. semanticscholar.org/e8c8/68af3e3dc8d0427c9cfabc47478b674014b4.pdf>. Acesso em: out. 2015.

MARCHETTI, J. A.; MAVROIDIS, P. C. The genesis of the GATS (General Agreement on Trade in Services). The European Journal of International Law, v. 22, n. 3, 2011.

MCGREGOR, J. EU quietly asks Canada to rework trade deal's thorny investment clause. CBC, 21 Jan 2016. Disponível em: <https://bit.ly/2OJAuBL>. Acesso em: set. 2016.

MEAD, W. R. The Jacksonian tradition: and American foreign policy. The National Interests, n. 58, p. 5-29, 2000.

MERTINS-KIRKWOOD, H. et al. Making sense of CETA: an analysis of the final text of the Canada-European Union Comprehensive Economic and Trade Agreement. 2nd ed. Berlin; Ottawa: PowerShift; CCPA, 2016. Disponível em: $<$ https://www.tni.org/files/publication-downloads/making-sense-of-ceta-2018. pdf>. Acesso em: out. 2016.

MINER, S. Commitments on state-owned enterprises. In: SCHOTT, J. J.; CIMINO-ISAACS, C. (Ed.). Assessing the Trans-Pacific Partnership: innovations in trading rules. Washington: PIIE, 2016. v. 2. Disponível em: $<$ https://bit.ly/1t1adj0>. Acesso em: out. 2016.

MORRIS, E. Renegotiating data localization: the role of provincial law in NAFTA e-Commerce. Information Security and Privacy Law, 21 Mar. 2018. Disponível em: <https://bit.ly/2MMAUVw>. Acesso em: 5 jul. 2018.

REINISCH, A.; MALINTOPPI, L. Methods of dispute resolution. In: MUCHLINSKI, P.; ORTINO, F.; SCHREUER, C. (Ed.). The Oxford handbook of international investment law. Oxford: Oxford University Press, 2008.

SCHOTT, J. J.; KOTSCHWAR, B.; MUIR, J. Understanding the Trans-Pacific Partnership. Washington: PIIE, 2013.

SEN. Brown statement on announcement that Japan will join in Trans-Pacific Trade talks. Sherrod Brown Senator for Ohio, 12 Apr. 2013. Disponível em: $<$ https://bit.ly/2YKtvrZ>. Acesso em: set. 2014.

SINCLAIR, S.; TREW, S.; MERTINS-KIRKWOOD, H. Making sense of CETA: an analysis of the final text of the Canada-European Union Comprehensive Economic and Trade Agreement. Ottawa: CCPA, 2014. Disponível em: <https:// bit.ly/1BLIQ9o>. Acesso em: set. 2016. 
SONG, Y. KORUS FTA vs. Korea-EU FTA: why the differences? Academic Paper Series, v. 6, n. 5, 2011. Disponível em: <https://bit.ly/2KD72Z3>. Acesso em: mar. 2016.

SUMMARY of the Trans-Pacific Partnership agreement. Office of the United States Trade Representative, 4 Oct. 2015. Disponível em: <https://ustr.gov/ about-us/policy-offices/press-office/press-releases/2015/october/summary-transpacific-partnership>. Acesso em: mar. 2016.

UNITED STATES OF AMERICA. Office of the United States Trade Representative. Fact sheet: Investor-State Dispute Settlement (ISDS). Washington: USTR, Mar. 2015.

VIGEVANI, T. $\mathbf{O}$ contencioso Brasil $\mathbf{x}$ Estados Unidos da informática: uma análise sobre formulação da política exterior. São Paulo: Alfa Omega, 1995.

WHITE, B. Obama aides: Warren "baseless" on trade. Politico, 6 May 2015. Disponível em: <https://politi.co/2YPjE43>. Acesso em: mar. 2016.

WTO - WORLD TRADE ORGANIZATION. Restrictive business practices and trade in services: MTN.GNS/W/99. Switzerland: WTO, 25 Apr. 1990. Disponível em: <https://bit.ly/2Kyp3ZL>. Acesso em: abr. 2016. 